\title{
National Parliaments: Obstacles or Aid to the Impact of International Human Rights Bodies?
}

\author{
JASPER KROMMENDIJK
}

This chapter argues that parliaments are an important actor facilitating the realisation of human rights. It shows that some recommendations of UN human rights treaty bodies (COs) have been effective and resulted in change as a result of the efforts of Members of Parliament (MPs) in the Netherlands, New Zealand and Finland. Nonetheless, parliaments can also pose an obstacle to the implementation of international human rights and COs. A wide parliamentary consensus on a certain practice is sometimes used as a simple excuse (by the government) for not acting upon the recommendations put forward in the COs. At the same time, MPs can be selfrighteous and critical about the quality of UN human rights treaty bodies and hence argue against the implementation of COs. The last part of this chapter presents a tentative list of domestic variables conditioning the (difference) in the engagement of parliaments with COs.

\subsection{Introduction}

How can parliaments influence the impact of international (human rights) law? Is their contribution always in favour of implementation of international norms or can they also work against and be an obstacle to the realisation of human rights? Policy documents seem to suggest that the greater the involvement of parliaments in international human rights law processes, the more beneficial this is from a human rights perspective. The Parliamentary Assembly of the Council of Europe and the recent Council of Europe Brussels Declaration have, for example, called upon States to better involve parliaments in the process of implementing judgments of the European Court of Human Rights (ECtHR) (JCHR 2010, paras. 15-17; Pourgourides 2010, 39; Rieter 2012; Brussels Declaration 2015). Likewise, the UN High Commissioner for Human Rights and UN human rights treaty bodies have recommended that parliaments monitor the implementation of recommendations of treaty bodies (CEDAW 2010, para. 8; Pillay 2012, 85). On the other hand, recent 
'incidents' actually suggest that this strategy is not always useful, as the (initial) resistance in the British Parliament to the now famous judgment of the ECtHR on prisoner voting in Hirst illustrates (Hunt, Hooper \& Yowell 2012, 9-10; Bates 2014). Slow or contested compliance with human rights judgments can thus occur when MPs and other actors aim to protect the democratic decision-making process and the position of Parliament as the guardian of the rule of law, also because they are afraid of negative headlines in the British newspapers ('the Daily Mail effect'; Cali \& Wyss 2009, 12, 15).

These opposing observations suggest that there is still a lot of uncertainty about the role of parliaments in relation to international human rights law. The two questions presented earlier have indeed received little academic attention and are, for example, not addressed in Conant's excellent chapter where it is noted that national courts are the most important actors enforcing international rights (Conant, this volume). To date, the role of parliaments in relation to international human rights law has hardly been researched in a systematic way, except for some studies on the ECtHR (Donald \& Leach 2015, 2016; Multirights 2015; Squatrito 2015). This has been even truer for the UN human rights treaty bodies, which generally suffer from scholarly neglect. The most widely accepted method for treaty bodies to monitor the implementation of UN human rights treaties, besides the optional individual complaint procedure, is the process of reporting. This reporting process stems from the obligation of State parties to submit periodically, usually every four or five years, a report on the implementation of each UN human rights treaty they have ratified. A committee or treaty body consisting of independent experts examines this report. Civil society and non-governmental organisations (NGOs) can also submit so-called shadow or parallel reports to the treaty body, which usually contain a more critical view and recommendations. The most important element of the human rights assessment by the treaty body is the discussion ('constructive dialogue') between the treaty body and the representatives of the State party in Geneva or New York. The treaty body subsequently adopts legally non-binding recommendations, concluding observations (COs).

This chapter aims to answer the following research questions: what has been the impact of the COs of the treaty bodies on parliaments? In what way have parliaments contributed to the effectiveness of COs? Which domestic variables, primarily those relating to the (institutional) organisation and functioning of parliament, condition this impact and effectiveness or lack thereof? For the purpose of this chapter, the six oldest 
treaty bodies have been examined (Table 10.1). In addition, three established democracies (the Netherlands, New Zealand and Finland) were selected because they are considered most-likely cases in the sense that they are generally seen as obedient compliers with international law and human rights in particular (see Section 10.2.2).

Table 10.1 Overview of the six main UN human rights treaties and treaty bodies

\begin{tabular}{lc}
\hline \hline UN human rights treaty & Treaty monitoring body \\
\hline $\begin{array}{c}\text { Convention on the Elimination of All } \\
\text { Forms of Racial Discrimination }\end{array}$ & $\begin{array}{c}\text { Committee on the Elimination of Racial } \\
\text { Discrimination (CERD) }\end{array}$ \\
$\begin{array}{cc}\text { ICERD) [adopted in 1965] } \\
\text { International Covenant on Civil and }\end{array}$ & Human Rights Committee (HRC) \\
Political Rights (ICCPR) [1966] & \\
International Covenant on Economic, & Committee on Economic, Social and \\
Social and Cultural Rights (ICESCR) & Cultural Rights (CESCR) \\
[1966] & \\
Convention on the Elimination of All & Committee on the Elimination of \\
Forms of Discrimination against & Discrimination against Women \\
Women (CEDAW) [1979] & (CEDAW Committee) \\
Convention against Torture and Other & Committee against Torture (CAT \\
Cruel, Inhuman or Degrading & Committee) \\
Treatment or Punishment (CAT) & \\
[1984] & \\
Convention on the Rights of the Child & Committee on the Rights of the Child \\
(CRC) [1989] & (CRC Committee) \\
\hline \hline
\end{tabular}

It should be stressed from the outset that treaty bodies are not international courts (ICs) in the classical sense and their output is legally nonbinding. That does, however, not make them irrelevant to study when dealing with ICs and domestic politics, because similar phenomena are at stake. The examination of treaty bodies is especially appropriate for three reasons. First, COs are more than merely advisory. They are increasingly seen as authoritative statements or interpretations that cannot easily be ignored by States (Steiner 2000, 52; Dimitrijevic 2001, 198; O'Flaherty 2006). The International Law Association (ILA), for example, observed that treaty body pronouncements are 'more than mere recommendations that can be readily disregarded' (ILA 2004, para. 15). There are also some judgments of national courts that give support to a stronger status of COs 
because the COs were accorded persuasive or moral authority (ILA 2004, paras. 32-33). Treaty bodies can and should, thus, be taken seriously as some type of judicial body.

Second, another reason for examining treaty bodies is that these bodies could be more accessible for individuals and NGOs than their more juridical counterparts such as the European Court of Human Rights (ECtHR) or the Court of Justice of the European Union (CJEU). Treaty bodies can at times offer more opportunities for individuals to have their complaints and grievances heard in relation to issues that such bodies and other ICs cannot handle because they fall outside the scope of the treaty or they have locus standi requirements that are difficult to fulfil. NGOs may be more likely to gain support from treaty bodies especially for issues that pertain to economic, social and cultural rights. This is also because treaty bodies are known for their sometimes activist approach and willingness to adopt a progressive interpretation of the treaties, which might be questionable from a strictly legal point of view, but strategically advantageous for NGOs and individuals (Acar 2007, 342; Krommendijk 2014, 196-7, 251).

Third, another argument for doing research on treaty bodies is that there are already many studies on the impact of regional courts, such as the ECtHR and the Inter-American Court of Human Rights (IACtHR) (Anagostou 2010; Hawkins \& Jacoby 2010; Hillebrecht 2014). By contrast, treaty bodies and the process of State reporting have so far been almost completely neglected even though they constitute one of the most important international mechanisms to monitor the implementation of UN human rights treaties (Connors 2000, 4; Kälin 2012, 16). The little research conducted so far has shown that treaty bodies have had some impact, albeit rather limited (Byrnes 2000; Heyns \& Viljoen 2001; Zwingel 2005; Krommendijk 2014).

This chapter contributes to the existing literature in two ways: first, by offering an empirical overview as to the impact of the COs on parliament and the role of parliament in contributing to the effectiveness of COs. Second, and maybe even more importantly, in identifying factors that (tentatively) influence the impact of COs and the way in which parliaments contribute to the COs' effectiveness, this chapter aims to contribute to theory building in the context of international relations (IR) and international law (IL) by adopting an exploratory or inductive approach. These independent variables might subsequently serve as a basis for the formulation of hypotheses that can be tested empirically in future research for their generalisibility in a more structured fashion. 
This chapter is based on $\mathrm{PhD}$ research that primarily examined the (domestic) impact and effectiveness of the treaty bodies in three countries (Krommendijk 2014). For the purpose of that research, 175 interviews were held with different domestic actors, including Ministers of Parliament (MPs), and a wide range of documents were studied, including parliamentary minutes and papers. In the context of this research, parliaments were approached as just one of the many relevant domestic actors in the 'domestic political field' (Wind Introduction this volume). This chapter will focus exclusively on parliaments and will attempt to isolate their role and contribution in relation to the effectiveness of COs.

The chapter is structured in the following way. The first section presents the research design, which includes a theoretical overview, a justification of the country selection and the methodology used to assess the impact and effectiveness of COs. The second section discusses the empirical results and shows how parliament can contribute to or obstruct the effectiveness of COs. The fourth section offers some explanatory factors for the parliaments' engagement with COs.

\subsection{Research Design}

Before presenting the theory review and the methodology, a couple of words should be devoted to semantics. Many terms are used to describe the effects of international law and courts at the national level, amongst others, 'impact', 'implementation', 'compliance', 'influence' and 'effectiveness'. The dependent variables in this chapter will be the impact and effectiveness. The term 'impact' is used to refer to the way in which parliaments have used or referred to the COs. 'Effectiveness' is used to describe the extent to which these COs have led to policy, legislation or any other measures. What distinguishes effectiveness from the most often used concept of 'compliance' is that the former implies a change whereas the latter merely requires a conformity between the COs and the policies and laws that are in place (Raustiala 2000, 388; Martin 2013; Krommendijk 2015). This chapter will also refer to the notion of 'engagement' with COs to capture the two phenomena of impact and effectiveness more generally.

\subsubsection{Theory Review}

In the legal human rights and IL literature, the focus has traditionally been on the interaction between ICs, monitoring bodies and domestic 
courts (ILA 2004; Keller \& Stone Sweet 2008) or the impact of international norms on the executive in terms of policy and legislative change (Cohn 1991; Risse, Ropp \& Sikkink 1999; Heyns \& Viljoen 2001; Niemi 2003; McQuigg 2007; Hawkins \& Jacoby 2010). Recognition is, however, increasing in the IR and the political science literature that other domestic actors and mobilisation matter for the impact and effectiveness of international law (Simmons 2009; Dai 2013; Hillebrecht 2014). The idea is that the effectiveness of international bodies depends upon the mobilisation of domestic advocacy groups, NGOs, MPs and the media in their ability and willingness to pressure governments to change their behaviour (Neumayer 2005, 930; Simmons 2009; Wind Introduction this volume). Hafner-Burton concluded that international norms must 'creep into domestic affairs [and] be taken up by local advocates' to be effective (Hafner-Burton 2013, 11). International institutions must thus 'co-opt' domestic actors 'from within' (Moravscik 1995). If they do, then they can act as 'tipping point actors' by strengthening the leverage and legitimacy of domestic actors and can give these compliance constituencies a powerful tool or additional argument (Alter 2011; see also Simmons 2009). Domestic compliance constituencies can thus be viable 'decentralised enforcers' who use international institutions as a focal point to legitimise their demands (Dai 2013; see in relation to courts, Conant this volume). A particular effective strategy for domestic actors is to voice their grievances at the international level with the idea of securing a critical recommendation or judgment that supports their views, which they than 'bring back home' to strengthen and amplify their demands so that the terms of the debate can shift. This what is commonly referred to as the 'boomerang effect' (Keck \& Sikkink 1999; Risse, Ropp \& Sikkink 1999). The central argument of these theories focusing on domestic and transnational mobilisation is, thus, that domestic change in relation to human rights is dependent on the presence and strength of domestic actors.

These and other studies on domestic and transnational mobilisation have not paid much structural and in-depth attention to the role of parliaments in relation to international (human rights) courts and monitoring bodies. ${ }^{1}$ Simmons, for example, focused on the executive, the judiciary, and citizens and NGOs as the three compliance mechanisms by

1 There is, however, considerable work as to the role of parliament in relation to domestic bills of rights (see Tushnet 1999; Waldron 2005; Hiebert 2006; Geddis 2011; Hunt, Hooper \& Yowell 2012; Hiebert \& Kelly 2015). 
which international human rights treaties influence change in rights policies and practices (Simmons 2009, 126-39). Some studies, however, recognise that parliament is one of the relevant domestic actors contributing to the implementation of judgments of international human rights courts (Baluarte \& De Vos 2010, 51, 55, 60; Hillebrecht 2012, 293). Anagnostou and Mugiu-Pippidi, for example, found that countries with the best record of implementation of ECtHR judgments, the UK and Austria, had the most extensive parliamentary involvement in the implementation process, while the countries with the worst record, Greece and Romania, had minimal involvement (Anagnostou \& Mugiu-Pippidi 2014). There is, however, not much attention paid to the way in which parliament really contributes to the implementation of international human rights law, albeit some recent studies have focus exclusively on parliament in relation to human rights treaties and judgments (Donald \& Leach 2015, 2016; Lupu 2015; Squatrito 2015).

Focusing on parliament is even more relevant in the case of the treaty bodies and their legally non-binding recommendations. Despite an increasing recognition that $\mathrm{COs}$ are authoritative interpretations by some domestic courts, COs have hardly been used in litigation because of the preference among litigants and courts for 'hard law' and judgments of the ECtHR (ILA 2004, paras. 175-9; Krommendijk 2014, 371). COs have thus primarily been used by NGOs in the political process of 'naming and shaming' the government with the idea of pressuring and mobilising parliament to request the government to change or take up the matter itself. Parliaments as such are thus better than courts when it comes to ensuring that $\mathrm{COs}$ are effective. As mentioned in the Introduction, this chapter has an inductive focus and aims to identify independent variables that affect the impact of COs and the way in which parliament contributes to the COs' effectiveness. Table 10.2 presents the variables, which will be thoroughly discussed in Section 10.5. 
Table 10.2 Overview of independent variables affecting the impact of COs on parliament and parliament's role in relation to the effectiveness of COs

\section{Structural or institutional factors}

Proportional representation vs. first past the vote voting system

Bicameral vs. unicameral parliamentary system

Separate constitutional or human rights committee vs. a mainstreamed human rights approach across parliamentary committees

Monist vs. dualist nature of the legal system (e.g. status of international human rights treaties and possibilities for judicial review)

Membership of a strong regional human rights system (e.g. ECHR/ IACHR)

\section{COs or treaty body dependent factors}

The level of other domestic actors informing and lobbying parliament about the COs

Salience and media coverage of the policy issue covered in the COs

MPs' direct engagement with the treaty bodies and the reporting process (e.g. submission of parallel report or attendance dialogue in Geneva)

The level of government informing parliament about the COs

\subsubsection{Country Selection}

The Netherlands, New Zealand and Finland were selected because they were considered most likely cases, countries from which you would expect the COs to be taken seriously. This choice was inspired by the existing literature on treaty bodies, which spoke about 'chronic' or 'distressing' levels of noncompliance and an 'implementation crisis of dangerous proportions' (Schmidt, Bayefsky \& Rodley 1997, 463). Even the Office of the United Nations High Commissioner for Human Rights (OHCHR) Secretariat held in 2006 that 'governments frequently pay insufficient attention to the recommendations adopted by the treaty bodies, and lack of awareness or knowledge among national constituencies about the monitoring procedures and their recommendations renders these invisible at the national level' (OHCHR 2006, para. 25). These statements are not surprising in the light of the many deficiencies in the functioning of the treaty bodies, which are well documented (Alston \& Crawford 2000; Keller \& Ulfstein 2012). If the system is to have any result, this would be in advanced and established liberal democracies, which generally take their reporting duties seriously and also have the resources to fulfil this burdensome task (LeBlanc, 
Huibregste \& Meister 2010; Conant this volume; Wind Introduction this volume). Established liberal democracies committed to the rule of law generally tend to have a better domestic human rights culture and more 'domestic constituencies' in the form of an active civil society, an independent judiciary, a strong parliament and a free press (Helfer \& Slaughter 1997, 329-30; Heyns \& Viljoen 2001; Hafner-Burton 2013).

Three relatively similar countries within the group of Western liberal democracies were chosen to limit the number of differing variables (Krommendijk 2014, 2015). The three countries are similar in not being federal States, which makes the implementation of international human rights law easier because there are generally fewer levels of government and veto players than in federal States (Heyns \& Viljoen 2001, 508). In addition, they do not have a Constitutional Court that would hamper reception of international human rights law as well since (strong) Constitutional Courts such as the German Bundesverfassungsgericht tend to base their judgments on domestic bills of rights (Helfer \& Slaughter 1997, 332-333; Keller \& Stone Sweet 2008, 686; Conant this volume). Besides the Netherlands, Finland was chosen out of the Nordic countries that generally integrate international reporting rather well in domestic policy processes (Connors 2000, 10). Finland, in particular, is seen as a consistent and dutiful complier with international (human rights) norms (Sverdrup 2004). Another practical reason for selecting Finland was the availability of academic literature in English about human rights and the impact of COs (Heyns \& Viljoen 2001; Niemi 2003; ILA 2004). New Zealand was selected from a list of nonEuropean Western democracies that also included Australia, Canada and the United States, because it is not a member of a regional (human rights) system, nor is it a federal State with a Constitutional Court. ${ }^{2}$

There are some similarities and differences between the three countries as to the institutional setup of the parliamentary and legal system, which relate to the independent variables presented in Table 10.2. The three countries are similar in the sense that they have a proportional voting system that has contributed to a multi-party system with many political parties represented in parliament. In the Netherlands and Finland, coalition governments have traditionally been the practice. New Zealand has also had coalition governments since 1996 as a result of the introduction of proportional voting in the same year. The three countries differ, however, in terms of the organisation

${ }^{2}$ It was deliberately decided to include a country that is not a member of a regional ((human rights) system (such as the ECHR or EU) to examine whether UN human rights treaties and the COs of treaty bodies have more impact in a country that only has these mechanisms with which to comply (see Krommendijk 2014). 
and operation of their parliamentary systems. First of all, the Dutch Parliament (States-Generaal) is bicameral and consists of the House of Representatives (Second Chamber) with 150 seats and the Senate (First Chamber) with 75 seats. Both New Zealand and Finland have a unicameral Parliament with respectively 120 and 200 seats. Second, the Netherlands and New Zealand do not have a specifically designated parliamentary committee that is tasked to deal with human rights. In Finland, the Constitutional Law Committee has a constitutional duty to issue statements on the conditionality of legislative proposals [...] as well as on their relation to international human rights treaties' (Sect. 74; Tuori 2012, 14-15). Third, both the Netherlands and Finland are monist with respect to their reception of international law, while New Zealand is dualist and requires treaties to be incorporated in national law before they can be given (direct) effect by national courts. Fourth, in Finland and New Zealand there is a strong belief in the sovereignty or supremacy of their Parliaments with only a very limited role of courts in terms of protecting human rights (Ojanen 2012, 106). Especially in New Zealand there is an idea 'that parliament can do anything' (Hopkins 2011, 429; Waldron 2005).

\subsubsection{Methodology}

A couple of words should also be devoted to the methodology used to assess the effectiveness of COs (Krommendijk 2014, 49-68, 2015). First, the level of effectiveness of COs was established, primarily on the basis of an analysis of the documents in which governments gave a reaction to the COs (periodic State reports and governmental letters to parliament) and the data gathered through the 175 semi-structured interviews with domestic human rights stakeholders in all three countries (government officials, NGO representatives, representatives from national human rights institutions, ministers and MPs). Several indicators were used to establish a relation between follow-up measures and COs (Krommendijk 2015). Second, based on IR and IL theories that posit that the effectiveness of international institutions depends upon their authority in the eyes of those who have to implement their output, government ministers and officials were asked about their views as to the authority of the treaty bodies (Franck 1990; Gibson \& Caldeira 1995; Hurd 1999). Third, various database searches of governmental and parliamentary papers, court judgments, NGO websites and newspaper articles were conducted to examine whether domestic actors, including MPs, used the COs in their work. It was, for example, examined whether MPs submit (written) parliamentary questions, motions or legislative proposals as 
a result or on the basis of the COs. For the Netherlands and New Zealand, a (database) search of parliamentary minutes and papers was conducted. ${ }^{3}$ For Finland, Petri Helander, Counsel to the CLC, undertook a search of documents of the Constitutional Law Committee (CLC). ${ }^{4}$ This quantitative and qualitative assessment of the impact of COs on parliament was complemented with the views from interviewees, including MPs, as well as academic literature about the level of mobilisation of parliament.

\subsection{Empirical Results}

\subsubsection{Impact of COs: The Extent to Which Parliaments Have Used or Referred to the COs}

The COs of the six treaty bodies have had some impact on parliaments in the three countries. MPs have often used the COs incidentally and in a reactive and opportunistic way as an additional argument or as support for their position with a reference to an 'authoritative' committee. MPs have particularly referred to COs when they were already active on a certain issue and when the COs were in the media. This also means that there has not been any structural interest in the parliaments in terms of monitoring the implementation of COs in a comprehensive way. MPs have primarily asked the government for a reaction to newspaper headlines, without reading the actual report or COs and without knowing anything about the reporting process. In addition, the level of engagement of parliament with respect to the COs has depended very much upon individual MPs (for a similar conclusion as regards the JCHR in the UK, see Hunt, Hooper \& Yowell 2012, 24). This is also because the awareness and knowledge of MPs of the reporting process and the COs are fairly limited. One example is a Dutch MP, Bussemaker (Labour), who alone raised eleven written parliamentary questions in which the Committee on the Elimination of Discrimination against Women (CEDAW) was referred to in a period of three years, with one reference to the COs of the CEDAW Committee (TK 2001/02b; Krommendijk 2014, 170). Note that there has been no direct or proactive interaction between parliaments and the treaty

3 Two Dutch databases were used for the period 1 September 1995 until 31 August 2011: parlando.sdu.nl (currently out of operation) and zoek.officielebekendmakingen.nl. For New Zealand this was Hansard for the period 1 January 2000 and 14 June 2012. Different search terms were used. For a full overview, see Krommendijk 2014, 417-25.

${ }^{4}$ Helader used the word 'komitea' (committee) for the period between 1 January 2004 and 13 May 2013. 
bodies, except the one instance in which the New Zealand Maori Party submitted an alternative report to the Committee on the Elimination of Racial Discrimination (CERD) (Maori Party 2007).

The Dutch Parliament has been most engaged with international reporting processes. Dutch MPs have been fairly active in using or referring to the COs of the CRC Committee and - to a lesser extent the CEDAW Committee. By contrast, the New Zealand Parliament has hardly been active in relation to the process and the follow-up to the COs, except for the COs of CERD pertaining to the controversial issues of the position of the indigenous Maori population. The Finnish Parliament takes a position somewhere in the middle.

\subsubsection{Effectiveness: The Extent to Which COs Led to Policy, Legislative or Any Other Measures}

Since the mid-1990s, 74 legislative, policy and other measures have been taken in the Netherlands, New Zealand and Finland as a result of the COs (Krommendijk 2014, 372). At the same time, the great majority of the COs has, however, remained ineffective. Approximately 900 out of a total of more than 1000 COs have not had any effect whatsoever, because they were either explicitly dismissed by the government or the government simply pointed to existing initiatives coinciding with the COs and argued that the COs were already complied with sufficiently (Krommendijk 2015). While Wind argues that domestic politics sometimes have the upper hand vis-à-vis ICs, these figures show that domestic politics often trump in the case of UN human rights treaty bodies (Wind Introduction this volume). Most of the measures taken as a result of the COs were related to the COs of the Committee on the Rights of the Child, at least in absolute terms: thirty-three of the seventy-four effective COs.

The role of the Dutch Parliament has been more important in contributing to the effectiveness of COs. What has happened more often in the Netherlands is that the government (initially) dismissed the COs and that it was only willing to proceed after pressure by domestic actors, such as NGOs, courts or Parliament. By contrast, the effectiveness of COs in New Zealand and Finland has been more executive driven with a smaller involvement of their Parliaments. The primary reason for the effectiveness of COs in New Zealand is the various CRC Work Programmes adopted by the government in 2000 to 2008, which contained concrete targets or milestones for policy or legislative action on the basis of COs of the CRC Committee. This CRC Work Programme has been an important factor in 
the effectiveness of almost half of all effective COs in New Zealand (Krommendijk 2014, 308-10). In Finland, the effectiveness of COs has also been more government driven. As already pointed out, there has been more of a legalistic compliance culture among Finnish officials and a greater tendency to accept external criticism than in the other two countries (Husa 2010; Ojanen 2012, 98; Krommendijk 2014, 325, 355, 359-60). This also means that fewer COs have been rejected by the Finnish government or remained completely unaddressed. There is an idea among government officials that strong counterarguments are needed when acting differently from the COs. By contrast, COs are seen more as non-binding opinions by Dutch and New Zealand officials. This also means that the Finnish government has been more willing to act upon COs in the absence of domestic mobilisation of NGOs and Parliament. This can also be attributed to the more positive stance of Finnish officials about the importance of reporting as a learning exercise and the quality of the treaty bodies. In addition, the Finnish Ministry of Foreign Affairs has been important in urging other ministries to act upon COs. As a result of the greater willingness of the Finnish government (officials) to respond to COs, there has been less contestation and mobilisation in Finland than in the Netherlands. The Finnish government has been described as 'a government civil society and a civil society government' (Pesonen \& Riihinen 2002, 284).

\subsubsection{Parliament as Driver for Effectiveness}

It has been shown elsewhere that the greater effectiveness of the COs of the CRC Committee can be attributed to the higher level of mobilisation of domestic actors such as NGOs, the media and MPs (Krommendijk 2015). Domestic actors have been considerably less active with respect to the other UN human rights treaties. Each of the three Parliaments has been an important actor facilitating the effectiveness COs on some occasions. Some COs have been effective and resulted in change partly as a result of the efforts of MPs. This section will present several examples to illustrate the potential of parliaments as drivers for the effectiveness of COs. Three modalities of a parliament's contribution to the effectiveness can be distinguished. First, MPs have sometimes vetted bills on the basis of the COs. Second, parliaments have pressured the government to take policy or legislative measures in line with the COs. Third, parliamentary attention for the COs has led to studies and evaluations or has put an issue (higher) up on the political agenda.

10.3.2.1.1 MPs Vetting a Bill One of the clearest examples of MPs taking action themselves on the basis of the COs is the establishment of 
a Children's Ombudsman, which was recommended three times by the CRC Committee (CRC 1999, para. 12). The Dutch government was unwilling to establish a separate ombudsman institution primarily for financial reasons. It was as a result of a legislative proposal by the MP Khadija Arib (Labour) that the first Children's Ombudsman eventually took office on 1 April 2011. Arib made clear that her legislative proposal was based on the COs of the CRC Committee (TK 2001/02c). What's more, Arib also used the COs as a supporting argument for her proposal. Several other MPs also mentioned the COs as a reason for the establishment of the Children's Ombudsman on nineteen occasions, including in two motions. Interviewed government officials and NGO representatives stressed the crucial role of the pressure and political interest of Parliament for the COs to be effective. A contributory factor to the effectiveness of the COs was the considerable media attention to the COs as well as the lobby of NGOs (especially Defence for Children International and UNICEF) that advised Arib on the matter.

Something similar happened in New Zealand with COs of the CRC Committee urging the government to prohibit corporal punishment. It was as a result of the COs of 3 October 2003 that MP Sue Bradford (Green Party) announced her Private Members Bill three days later (CRC 2003, paras. 29-30). Bradford explicitly stated that she was 'stirred into political action by the recommendations that the UN Committee on the Rights of the Child made on two occasions' (Wood et al. 2008, 204). The COs and the CRC were useful and gave her and other advocates a strong position to discuss the matter with government ministers. They offered an (international) endorsement and an additional level of legitimacy as justifications for change. As in the Dutch case, an important factor contributing to the COs' effectiveness was the strong lobbying of NGOs, with which Bradford had regular contact and which also advised her on certain issues (Wood et al. 2008, 190).

10.3.2.1.2 MPs Pressuring the Government to Act COs have also offered useful tools for MPs to pressure the government to take action in line with the COs. One notable example of this category is the pressure exercised by the Dutch Parliament, especially by left-wing opposition parties, on the government with respect to the treatment and detention of refugee and asylum-seeking children, which was criticised several times by the CRC Committee (CRC 1999, para. 28). The COs were initially disregarded by the centre-right governments of Balkenende I-III (2002-7) because legislation was already deemed to be in conformity with international norms (TK 2003/04a, 8). These governments were 
reluctant to change the legislation on the basis and result of (nonbinding) COs. Nonetheless, a new policy was developed on the basis of the principles of the CRC, and there was a big shift towards less detention of minors both at the political level and in practice (TK 2005/06a; Smits-Baauw \& Van Os 2007, 2). This policy change was partly the result of the extensive pressure in Parliament, more specifically by way of two motions requesting that government consider alternatives for parents with children in detention (TK 2005/06b; TK 2006/07). In their political lobby, MPs used domestic and international criticism from a plethora of bodies. The COs were one of the many useful sources that kept the issue on the political agenda and increased the pressure on the government. Three earlier motions, which did not get a parliamentary majority, did, for example, refer to the COs (TK 2003/04b). The strong parliamentary focus on this issue and the use of COs by MPs can be attributed to the extensive lobbying on the part of NGOs, which had organised themselves in the Coalition 'No child in a cell' and used the COs as an important tool. This Coalition, for example, presented 138,212 signatures in June 2006 to several MPs, including those who subsequently proposed the decisive motion. Another contributory factor for the considerable parliamentary engagement with the COs is the significant coverage of the issue by the media, which used an eight-year-old Chinese boy in detention as a figurehead.

\subsection{MPs Attention Leading to Studies and Setting the Political} Agenda MPs have also used the COs to call for more attention to a certain issue in the form of studies. One example of this category relates to the COs of the CEDAW Committee recommending the amendment of the Law on Names, which provides that the child will automatically receive the name of the father when the parents cannot reach an agreement about the child's name (CEDAW 2001, paras. 223-4). Again, the Dutch government dismissed the COs and made clear that it did not share the CEDAW Committee's opinion that the Law on Names contravenes the CEDAW. One MP proposed an amendment to the Law on Names but eventually withdrew it after the Dutch Council of State, which advises on the quality of legislation, gave a negative opinion. Several MPs, nonetheless, continued with pressuring the government to act and referred to the COs on eight occasions during parliamentary debates or in written parliamentary questions. Eventually, the repeated attention to the COs by several MPs over a number of years resulted in the Minister of 
Justice Hirsch Ballin promising to establish a working group that would also examine the Law on Names in the light of the COs.

Another Finnish example is the criticism from several UN human rights treaty bodies as well as other international and European (human rights) monitoring organisations about the land rights of the indigenous Sami reindeer herders that are undermined by forestry and mining activities. The COs were an important factor in the public and political debate and were highlighted in parliamentary discussions. The COs kept the issue almost constantly on the (political) agenda and also increased the pressure to proceed with the matter. The COs and other international criticism have led to numerous reports as well as some unsuccessful legislative attempts to settle the question of Sami land rights (Semb 2012; Krommendijk 2014, 347-8).

\subsubsection{Parliaments as Obstacles for the Effectiveness of COs}

Parliaments do not only contribute to the effectiveness of COs. They can also pose an obstacle to the implementation of international human rights and COs as well (Donald \& Leach 2015, 87; Wind Introduction this volume). First, a wide parliamentary consensus on a certain practice can be used as a simple excuse (by the government) for not acting upon COs (see Section 10.3.2.1). Second, MPs can be self-righteous and critical about the legitimacy and quality of UN human rights treaty bodies and the COs and consequently argue against the implementation of COs (this section).

\subsection{Wide Parliamentary Consensus as an Excuse to Do} Nothing The three governments have sometimes used the parliamentary consensus as an excuse for not following the COs. ${ }^{5}$ They have primarily pointed to the ex ante parliamentary endorsement in the form of an extensive and careful discussion or the coalition agreement among the ruling political parties as 'fig leafs' for inaction. This has especially happened in the Netherlands where international criticism of the Dutch 'liberal' practices such as abortion, euthanasia and prostitution have often remained ineffective. COs related to these issues have simply not been taken note of by most domestic actors, because they have generally been considered political non-issues given the political and

5 The parliamentary scrutiny and discussion about the proportionality of a limitation to a human right could also be used when defending a case before the ECtHR or during the dialogue with the treaty bodies to justify certain policy or legislative measures (Donald \& Leach 2015, 84). 
parliamentary consensus in favour of these policies (Krommendijk 2014, 133). One example relates to the COs of the Human Rights Committee about the Dutch Medical Research (Human Subjects) Act, which makes it possible to conduct medical experiments with minors and other persons unable to give their consent (HRC 2001, para. 7). In its response to the COs, the government argued that it was not willing to change the law and underlined that the Dutch Parliament had already discussed the arguments for medical experiments extensively during the consideration of the bill. According to the government, Parliament had carefully weighed all arguments and also paid due regard to the compliance with treaty requirements (TK 2001/02, 6-7). With respect to euthanasia, the government likewise underlined that the concerns that were later expressed by the HRC in its COs had been at the forefront during the preparation of the legislative proposal and the parliamentary discussion. In addition, the government simply pointed to the coalition agreement determining that no amendments would be made in the period of office (TK 2009/10, 3). Another example is the earlier discussed criticism on detention of asylum-seeking children. In response to questions in Parliament about the COs, Minister for Immigration and Integration (VVD) Rita Verdonk simply referred to the coalition agreement that laid down the earlier agreed-upon restrictive immigration policy (TK 2003/04c, 1812). She argued that the immigration laws had been drafted together with the Parliament and that if Parliament considered amendments necessary, it should be up to Parliament to make this explicit (TK 2003/04d, 5851).

\subsection{Self-righteous and Defensive Reactions MPs have not} always been in favour of acting upon the COs. Especially New Zealand MPs have been self-righteous and critical about the legitimacy and quality of UN human rights treaty bodies and the COs. Quite a number of MPs referred to the criticism or recommendations of the treaty bodies with disapproval. MP Darren Hughes (Labour) noted, for example, that

people at the fringes of politics have become very excited about a report from a United Nations committee regarding the Foreshore and Seabed Act. But I think it is very important to put on the record that that overseas committee considered that important matter for simply 35 minutes, and that it was not a committee made up of countries that we could say have a better race relations record than New Zealand does.

(NZPD 2005a) 
Tony Ryall (National) argued in similar fashion: 'New Zealand has made it quite clear to all the international agencies that we will not follow their rules as we have our own rules' (NZPD 2005b). Future Minister of Justice Simon Power (National) was also critical about MPs who would like to have the recommendations of the HRC implemented 'lickety-split' (NZPD 2003). Likewise Gerry Brownlee (National) stated that 'New Zealanders don't need to be told by the UN what it means to be a Kiwi. Fair-minded Kiwis will reject these statements outright, because they know them to be untrue' (Brownlee 2005).

Similar developments can be observed in the Netherlands (Krommendijk 2014, 80-2). Several political parties and MPs have become more critical about international human rights treaties and monitoring in recent years. International human rights treaties are increasingly viewed as obstructing the implementation of intended policy initiatives, particularly in the field of immigration and integration. Then VVD (Liberals) Leader in the Second Chamber and the current Prime Minister Mark Rutte even referred to 'outdated European treaties' that prevent putting an end to the big flow of migrants (Rutte 2010). Criticism is also growing among politicians, both in Parliament and in government, as to international intervention in domestic affairs as well as domestic court judgments in relation to human rights (Oomen 2013, 308). More recently, the VVD and the PVV (right-wing), and to a lesser extent the CDA (centre-right Christian democratic), have been critical about the expansionist power and interpretation of the ECtHR (Donald \& Leach 2015, 71; Gerards 2015). Even relatively human rights-minded MPs such as Alexander Pechtold (D66/ centrist socialliberal) and Diederik Samson (Labour) reacted defensively to criticism of the European Commission on Racism and Intolerance (ECRI) in 2013 on the measures in place to address racial discrimination. Pechtold stated, for example: 'Yeah, well, then there are these independents organs that make an analysis once in a while ... I think we should always be alert ... but I do not think that we in the Netherlands are really out of tune with other countries' (Pownews 2013). Samson likewise held: 'I understand what the Council of Europe thinks about that [interviewer: Do you really understand?] Yes, well, I understand that looking to the Netherlands from the outside ... [why are they intervening!] I use very decent words to say more or less the same' (Pownews 2013).

Underlying such negative views of MPs in both New Zealand and the Netherlands is the feeling that there are no (grave) human rights problems in both countries, that international human rights treaties are already sufficiently complied with and that international criticism is 
unjustified (Butler \& Butler 2005, paras. 2, 3, 39, 35.9.2; Krommendijk 2014, 314-15). Several government officials share these views. UN human rights treaties and the treaty bodies are primarily seen as relevant for other countries. Oomen referred in this context to 'human rights exportism' where treaties are considered as yardsticks for others (Oomen 2013). International human rights are often considered irrelevant in domestic political debates and public discourse. When issues are framed in terms of human rights, this can lead to surprised or even dismissive responses, as the previously cited quotes illustrate as well. These sentiments explain - in addition to mere ignorance or limited knowledge about COs - why most COs have not had much impact in parliament and have remained ineffective. MPs have either actively argued against doing something on the basis of COs, or they have not put pressure on the government to act in line with COs.

\subsection{Explanatory Factors for the Parliaments' Engagement with COs}

This section will further explore several explanatory factors or independent variables that might account for the (difference) in the engagement of parliaments with COs, that is, the impact of COs on parliament and parliament's role in the effectiveness of COs (see Table 10.2 for an overview). The empirical results on only three established liberal democracies do not give sufficient ground to formulate some generalisable and definitive conclusions for contrasting States, such as recent democracies or States with malfunctioning parliaments as well as countries that are members of arguably weaker regional human rights systems, such as the Inter-American Commission on Human Rights (IACHR) and the African Charter on Human and Peoples' Rights (ACHPR). It is against this background that the following tentative observations are put forward, which should be tested in future research:

1. The impact and effectiveness of COs is larger in countries with a proportional electoral system. One factor that has contributed to the effectiveness of COs is the proportional electoral system in the three countries that have empowered small political parties. Such smaller parties have an incentive to use COs, because this can give them some authority and an additional lever in the debate or they can be used as a political tool to portray their party as rights friendly (Butler 2011; Geddis 2011, 471). COs have also been used somewhat 
more frequently by the relatively small Green Party in all three countries, or in the case of New Zealand the Maori Party (Butler 2011; Krommendijk 2014, 287, 361). What is more, the proportional electoral system also facilitates small parties initiating or prompting action on the basis of COs. The latter was the case with the earlier discussed bill prohibiting corporal punishment in New Zealand, which was proposed by an MP from the small Green Party (Sue Bradford).

2. The impact and effectiveness of $\mathrm{COs}$ is larger in countries with a bicameral parliamentary system. The empirical results for the Netherlands imply that having a second chamber is beneficial for parliament's engagement with COs. The Dutch Senate, which has traditionally operated as a 'chamber of reflection', has paid considerable attention to (ex ante) conformity with international (human rights) law and discussed this more extensively than the House of Representatives (Claes \& Leenknecht 2011, 292). There has also been considerable attention to the COs in the Senate (EK 2008/09; EK 2009/10; EK 2010/11). A study found similar results in the UK, where the House of Lords was found to engage more with human rights reports of the Joint Committee of Human Right than the House of Commons (Hunt, Hooper \& Yowell 2012, 25). Explanations for the less prominent role of the House of Representatives in relation to human rights, which might also be applicable for other countries, are the limited legal expertise to analyse jurisprudence of ICs and monitoring bodies; the great(er) turnover and, hence, limited experience of MPs; the absence of a collective or institutional memory; or the limited popularity of being involved in - the rather technical exercise of - legislation (Krommendijk 2014, 77). Even though Finland has a unicameral system, the Constitutional Law Committee has taken a largely similar role as the Dutch Senate. This Committee composed of politicians has been characterised as a legal expert body free of party politics that adopts a quasi-judicial approach and pays due regard to international (human rights) law and the output of treaty bodies (Niemi 2003, 31; ILA 2004, para. 160; Husa 2011, 198; Tuori 2012, 11-12).

3. The existence of a separate constitutional or human rights committee as such does not significantly affect the impact and effectiveness of COs. This observation also flows from the preceding paragraph, which discussed the similarities between the Dutch Senate and the Constitutional Law Committee in terms of ensuring that human 
rights arguments are sufficiently considered. The mainstreamed approach in the Netherlands, where no particular (sub)committee has a human rights mandate, but where human rights are considered across the board by different committees when they are relevant, has not prevented COs from having an impact (Donald \& Leach 2015, 71-2). No evidence suggests that the engagement of the Finnish Parliament with COs has been higher than that of the Dutch Parliament. There is, however, more of a difference between New Zealand, on the one hand, and the Netherlands and Finland, on the other hand. Because New Zealand has a unicameral system and/or no specially designated human rights committee, human rights matters and COs are not structurally embedded in the parliamentary system. The latter is further aggravated by the following two phenomena (points 4 and 5 following).

4. The formal legal status of international human rights treaties and the possibilities for judicial review by courts also affect the extent to which parliament pays attention to these treaties and COs. One factor that affects the engagement of both national courts and parliaments with international (human rights) law is the legal status of treaties in a country's legal order. This relationship is especially supported by the empirical result for New Zealand, where UN human rights treaties have not been legally incorporated. What's more, courts are precluded from declaring legislative enactments inconsistent with the New Zealand Bill of Rights Act and international human rights treaties. ${ }^{6}$ These treaties and treaty bodies have consequently had a much lower legal and political status. Knowing that courts cannot overturn legislation, the New Zealand Parliament has no incentive to examine the consistency of bills with the domestic Bill of Rights let alone UN treaties (Geddis 2011; Kelly 2011, 308-9). By contrast, when international human rights treaties are automatically part of the legal order (the Dutch monistic order) or legally incorporated (all UN treaties are incorporated in the Finnish dualist system), this offers more scope for domestic actors, including MPs, to rely on them. The reason is that courts have more possibilities to use international human rights

${ }^{6}$ See Sec. 5 of the New Zealand Bill of Rights. This act includes civil and political rights that mirror the ICCPR. Although the act has as its objective 'to affirm New Zealand's commitment to the ICCPR', the ICCPR is not directly incorporated and can therefore not be given effect by courts. The act has therefore been characterised as a 'parliamentary Bill of Rights', which is realised through political rights review in parliament instead of judicial review (Kelly 2011, 304). 
treaties, which at the same time has encouraged other actors to closely examine these treaties. The Finnish practice actually shows that the empowerment of courts in 2000 to disapply national laws when in conflict with the Constitution has positively affected the parliamentary ex ante scrutiny of bills and possibly also the impact of UN treaties and COs (Lavapuro, Ojanen \& Scheinin 2011, 524). ${ }^{7}$

5. Parliaments engage more with the COs in countries that are members of a strong regional human rights system, such as the Council of Europe. The impact and effectiveness of COs have, maybe counter-intuitively, also benefitted from the existence of a strong regional human rights system. This is well illustrated by Finland, where it was the late ratification of the ECHR in 1990 that was a 'turning point' and subsequently led to a growing profile and culture of human rights in general (Rosas 2001, 310-11; Lavapuro, Ojanen \& Scheinin 2011, 520; Tuori 2012, 9). Before that, when Finland had only ratified UN human rights treaties, human rights played an insignificant role in the legislative process, in the government bureaucracy and in parliamentary proceedings (Rosas 2001, 297). This early Finnish experience can be compared with the current situation in New Zealand, where the absence of a truly effective external human rights check in-line with the ECHR and ECtHR has facilitated Parliament's lack of interest or unwillingness to examine human rights matters. At the same time, the CRC and CEDAW have had more impact than that of other UN treaties in the Netherlands because they do not face 'competition' in the form of equivalent provisions in regional treaties (see next point).

6. The level of parliament's engagement with COs depends upon other domestic actors informing and lobbying parliament to take due account of the COs. The tentatively most important factor affecting the engagement of parliament with the COs is the mobilisation of civil society actors, such as professional organisations of judges or lawyers or comments of academics, but especially NGOs (Hillebrecht 2014, 22-4; Saul 2015; Squatrito 2015). The previous section showed that when parliaments had contributed to the effectiveness of COs, this was often (partly) the result of and facilitated by the work of NGOs. MPs are generally eager to make use of commentaries and information from NGOs, because of the limited time they have at their disposal.

7 A constitutional amendment in 2000 empowered Finnish courts to not apply a statutory provision when the provision 'would be in evident conflict with the Constitution' (Sec. 106). 
The lobbying of NGOs has often been a major reason for MPs to allude to COs. One example from New Zealand is the media release of MP Jan Logie (Green Party) in which she highlighted the criticism of the Committee on Economic, Social and Cultural Rights concerning welfare reforms (Radio New Zealand 2012). The NGO Peace Movement Aotearoa brought the criticism to her attention (Logie 2012). Likewise, the Dutch Labour MP Hans Spekman asked the government to react to several COs of CESCR as a result of a conversation with a professor of human rights. Spekman had never heard of CESCR and its COs even though he dedicated himself especially to the rights of undocumented migrants and children (Spekman 2011). Further support indicating the dependency of MPs on NGOs is the relatively high impact of the COs of the CRC Committee and the CEDAW Committee in the Netherlands. Table 10.3 shows that the COs of the CRC Committee have been mentioned in more parliamentary papers by the parliament (in fiftysix parliamentary papers) than all the other five treaty bodies together (in forty-one parliamentary papers). The COs CEDAW Committee occupies second place. This is not surprising in the light of the strength and professionalism of the Dutch Children's Rights Coalition and the Dutch CEDAW Network, which have both invested heavily in reporting under both treaties and monitoring as follow-up to COs. Both NGOs have, for instance, sent parliament their comments on the government's response to the COs. They have also organised conferences and seminars to discuss follow-up with MPs or sometimes even with the responsible minister. The comments of these NGOs have often been explicitly mentioned by MPs during parliamentary debates (TK 2008/09, 4, 5). The focus of NGOs on reporting under the CRC and - to a lesser extent - CEDAW can also be explained by the fact that these treaties are the most important points of reference for children's and women's rights. No regional equivalents for the CRC and CEDAW are more comprehensive and offer stronger remedies. By contrast, NGOs and other domestic actors prefer Council of Europe mechanisms over the closely related but weaker UN human rights treaties: the European Committee for the Prevention of Torture and Inhuman or Degrading Treatment or Punishment (ECPT) instead of the Committee against Torture, the ECtHR instead of the International Covenant on Civil and Political Rights, European Commission against Racism and Intolerance (ECRI) instead of CERD and the European Social Charter (ESC) instead of CESCR. 


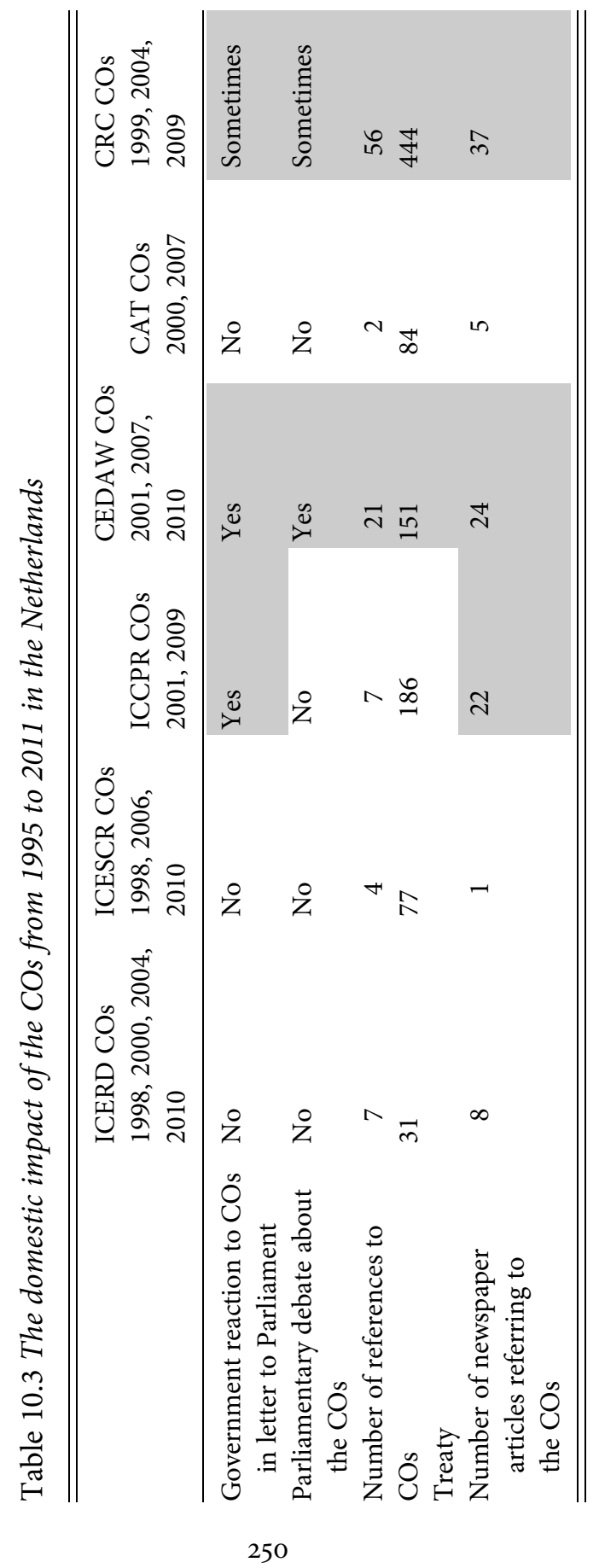


7. The level of parliament's engagement with COs depends upon the salience and media coverage of the policy issue covered in the COs. Another related explanation for the parliamentary engagement with COs is the salience of the issues that are dealt with in the CO. The greater impact and effectiveness of COs of the CRC Committee in all three countries can, for example, be explained by the topical interest in the issue of children's rights (Simmons 2009, 357-8). Children's rights meet a clear response in the wider society and parliament and hardly anyone is openly against children's rights because children are generally considered to be in a vulnerable position. Children are more mediagenic and can be more easily used as figureheads, such as the example of the Chinese asylum-seeking child already noted. By contrast, other groups such as prisoners, criminals and migrants generally profit less from such a beneficial status. There is a close connection between the salience of an issue and the degree of media attention. Parliamentary attention is primarily driven by newspaper headlines. Several interviewees noted that when COs are not reported in the media, it is often difficult for MPs to use COs or to put them on the agenda. The great influence of the media was also attributed to the information overload and lack of time for MPs and the pressure to attract media coverage. The importance of media coverage for the attention in parliament is illustrated by the fact that media attention for reporting under CRC and the COs of the CRC Committee has been significantly higher than any of the other five treaty bodies (see Table 10.3). Thirty-seven of the ninety-seven articles referring to the reporting process under all six treaties related to the CRC Committee (Krommendijk 2014, 256).

8. The level of parliament's engagement with COs depends upon MPs' direct engagement with the treaty bodies. The actual use made of COs by MPs can also be influenced by their direct engagement with the treaty bodies. A first example is the Maori Party in New Zealand, which was directly involved in reporting by way of submitting an alternative report to CERD in May 2007 (Maori Party 2007). This political party was actually founded in 2004 as a result of the Foreshore and Seabed Act 2004, which conferred the ownership of the foreshore and seabed to the State to safeguard public access to beaches. The Maori were vocally opposed to this act and argued that they were the rightful owners based on historical possession. NGOs voiced their grievances with CERD, which concluded in 2005 that the act contained 'discriminatory aspects' against Maori. The boomerang 
thrown by Maori NGOs to Geneva returned to New Zealand and was used by Maori NGOs that had close contacts with Maori MPs, who subsequently also used the COs during parliamentary debates to strengthen their criticism vis-à-vis the government. The COs of CERD were used on several occasions, almost always by MPs from the Maori Party. Table 10.4 shows that CERD is the most often referred to treaty body in the New Zealand Parliament. A second example is the Finnish case. There were 'a significant number of cases' around the 2000s during which the Constitutional Law Committee relied on the output of the HRC, mostly the views of the HRC and not so much the COs (ILA 2004). Some Finnish interviewees noted that this reliance was the result of the academic Scheinin, who was a member of the HRC from 1997 to 2004. The Constitutional Law Committee regularly consulted him during this period. Some interviewees noted that when Scheinin went abroad, the output of the HRC was discussed less often. This has been alleviated in recent years as a result of the dialogues with treaty bodies by individual MPs since 2005. The MP Elisabeth Nauclér from the Swedish People's Party of Finland who attended CEDAW 2008, stated that she would report back to Parliament on the outcome of the dialogue and 'would be attentive to follow-up' (CEDAW 2008, para. 66). Nauclér indeed organised a discussion meeting about CEDAW and the reporting process, and she mentioned CEDAW and the COs several times in a number of speeches. She felt inspired by the dialogue and did not deride the quality of the CEDAW Committee (Nauclér 2013). Future research should examine whether this dialogue has had a considerable effect, given that only five Finnish MPs have been to Geneva since 2005, and whether such attendance has a positive effect as well. It could also be that MPs are actually discouraged from using the COs after having seen the treaty bodies in action themselves, because they are disappointed in the functioning and level of quality of the treaty body and dialogue. The latter has especially happened with Dutch and New Zealand government officials (see Section 10.3.2.2.2; Krommendijk 2015). 
Table 10.4 Number of occasions during which MPs referred to various treaties, treaty bodies and COs in New Zealand (2000-2012)

\begin{tabular}{lll}
\hline \hline & Treaty or committee & COs \\
\hline CAT & 23 & 9 \\
ICERD & 24 & 13 \\
ICESCR & 6 & 0 \\
CRC & 72 & 6 \\
CEDAW & 7 & 5 \\
ICCPR & 50 & 2 \\
\hline \hline
\end{tabular}

9. The level of parliament's engagement with COs depends upon the extent to which the government has informed parliament about the COs. Another important factor that affects the engagement of parliament is the extent to which the government informs parliament about the reporting process and the COs. Such informing has mostly been developed in the Netherlands, where the Dutch government generally sends most UN documents in the context of the reporting process (State reports and List of Issues) to Parliament. What is more, the Dutch government has also sent its response to the COs of some treaty bodies to Parliament. There have even been debates in Parliament on the basis of the government reaction (see Table 10.3). The Dutch practice stands in sharp contrast with that of New Zealand, where no information whatsoever is sent by the government to Parliament. MP Keith Locke (Green Party) held that had NGOs not been involved in the process or been to Geneva, no information would get through to New Zealand (Locke 2012). Note that merely sending documents to parliament is surely not enough, because MPs are confronted with piles of paper and full email inboxes every day, so the importance of this factor should not be underestimated (see also Donald \& Leach 2015, 74).

\subsection{Conclusion}

This chapter examined the way in which parliaments adapt to or utilise the output of international human rights monitoring bodies, the COs. It showed that parliament is a relevant actor to consider when it comes 
to the implementation of COs. Even though the treaty bodies are strictly speaking not ICs, the empirical observations are relevant for the discussion of ICs and domestic politics. Similar domestic variables affect the engagement of parliaments with judgments of (human rights) ICs. This chapter showed that parliaments have at times used some COs as useful tools domestically. What is more, parliaments can also contribute (in)directly to the effectiveness of COs. MPs can do so in different ways, by vetting a bill on the basis of the COs themselves or by pressuring the government to act upon the COs. The level of parliament's engagement with COs depends very much upon other domestic actors informing and lobbying parliaments to take action on the basis of COs. Parliaments have, however, not always favoured the implementation of COs and have sometimes even posed an obstacle to their realisation, especially in the Netherlands and New Zealand.

This chapter has formulated some tentative conclusions as to the domestic variables that condition the impact and effectiveness of COs, which relate, among others, to the electoral system, the number of chambers and the existence of a separate human rights committee. It is to be hoped that future research will examine the role of parliaments in relation to international (human rights) courts and tribunals in a more systematic and in-depth way, possibly based on some of the tentative conclusions reached here. Parliaments not only matter when it comes to the implementation of international human rights from an empirical point of view but also from a more political-normative one. The (greater) engagement of parliament, as the primary locus of democratic decision making and legitimation, is desirable (Tushnet 1999; Hunt, Hooper \& Yowell 2012).

\section{References}

Acar, F. (2007). Thoughts on the Committee's Past, Hopes for Its Future. In C. Flinterman \& B. Schöpp-Schilling, eds., The Circle of Empowerment: Twenty-five Years of the UN Committee on the Elimination of Discrimination against Women, New York: The Feminist Press at the City University of New York, pp. 340-5.

Alston, P. \& Crawford J., eds. (2000). The Future of UN Human Rights Treaty Monitoring, Cambridge: Cambridge University Press.

Alter, K.J. (2011). Tipping the Balance: International Courts and the Construction of International and Domestic Politics. Cambridge Yearbook of European Legal Studies, 13, 1-21. 
Anagnostou, D. (2010). Does European Human Rights Law Matter? Implementation and Domestic Impact of Strasbourg Court Judgments on Minority-related Policies. The International Journal of Human Rights, 14(5), 721-43.

Anagnostou, D. \& M. Pippidi, A. (2014). Domestic Implementation of Human Rights Judgments in Europe: Legal Infrastructure and Government Effectiveness Matter. The European Journal of International Law, 25(1), 205-27.

Baluarte, D. C. \& De Vos, C. M. (2010). From Judgment to Justice. Implementing International and Regional Human Rights Decisions, New York: Open Society Foundations.

Bates, E. (2014). Analysing the Prisoner Voting Saga and the British Challenge to Strasbourg. Human Rights Law Review, 14(3), 503-40.

Brownlee, G. (2005). UN assumptions biased presumptions, 25 November 2005: www.scoop.co.nz/stories/PA0511/S00387.htm.

Brussels Declaration. (2015). High-level Conference on the 'Implementation of the European Convention on Human Rights, our Shared Responsibility', 27 March 2015, http://justice.belgium.be/fr/binaries/Declaration_EN_ tcm421-265137.pdf.

Butler, A. \& Butler, P. (2005). The New Zealand Bill of Rights Act: A Commentary, Wellington: LexisNexis NZ.

Butler, P. (2011). It takes two to tango. Have they learned their steps? Social Science Research Network.

Byrnes, A. (2000). Uses and Abuses of the Treaty Reporting Procedure: Hong Kong between Two Systems. In P. Alston \& J. Crawford, eds., The Future of UN Human Rights Treaty Monitoring, Cambridge: Cambridge University Press, pp. 287-315.

Çali, B. \& Wyss, A. (2009). Why Do Democracies Comply with Human Rights Judgments? A Comparative Analysis of the UK, Ireland and Germany. Social Science Research Network.

CEDAW (2001). Concluding Observations of the Committee on the Elimination of Discrimination against Women: The Netherlands. UN Doc. A/56/38.

CEDAW (2008). Summary Records: Finland. UN Doc. CECAW/C/SR.841.

CEDAW (2010). Concluding Observations of the Committee on the Elimination of Discrimination against Women: The Netherlands. UN Doc. CEDAW/C/ $\mathrm{NLD} / \mathrm{CO} / 5$.

Claes, M. \& Leenknecht, G. J. (2011). The Netherlands. A Case Of Constitutional Leapfrog. Fundamental Rights Protection under the Constitution, the ECHR and the EU Charter in the Netherlands. In P. Popelier, C. Van de Heyning \& P. Van Nuffel, eds., Human Rights Protection in the European Legal Order: The Interaction between the European and the National Courts, Cambridge: Intersentia, pp. 287-307. 
Cohn, C. (1991). The Early Harvest: Domestic Legal Changes Related to the Human Rights Committee and the Covenant on Civil and Political Rights. Human Rights Quarterly, 13(3), 295-321.

Connors, J. (2000). An Analysis and Evaluation of the System of State Reporting. In A. F. Bayefsky, ed., The UN Human Rights System in the 21st Century, The Hague: Kluwer, pp.3-21.

CRC (1999). Concluding Observations of the Committee on the Rights of the Child: The Netherlands. UN Doc. CRC/C/15/Add.114.

CRC (2003). Concluding Observations of the Committee on the Rights of the Child: New Zealand. UN Doc. CRC/C/15/Add.216.

Dai, X. (2013). The 'Compliance Gap' and the Efficacy of International Human

Rights Institutions. In T. Risse, S. C. Ropp \& K. Sikkink, eds., The Persistent

Power of Human Rights. From Commitment to Compliance, Cambridge: Cambridge University Press, pp. 85-102.

Dimitrijevic, V. (2001). State Reports. In G. Alfredsson et al., eds., International Human Rights Monitoring Mechanisms. Essays in Honour of Jakob Th. Möller, The Hague: Kluwer, pp. 185-200.

Donald, A. \& Leach, P. (2015). The role of Parliaments Following Judgments of the European Court of Human Rights. In M. Hunt, H. Hooper \& P. Yowell, eds., Parliaments and Human Rights: Redressing the Democratic Deficit, Oxford: Hart Publishing, pp. 59-92.

(2016). Parliaments and the European Court of Human Rights, Oxford: Oxford University Press.

EK 2009/10, 31994, nr. B.

EK 2008/09, 31436, nr. D.

EK 2010/11, 32211, nr. B8.

Franck, T. M. (1990). The Power of Legitimacy and Institutions, New York: Oxford University Press.

Geddis, A. (2011). Prisoner Voting and Rights Deliberation: How New Zealand's Parliament Failed. New Zealand Law Review, 443-74.

Gerards, J. (2015). The Netherlands. In P. Popelier \& S. Lambrechts, eds., Shifting the Convention System - Counter-Dynamics at the National Level, Antwerp: Intersentia, pp. 327-60.

Gibson, J. L. \& Caldeira G. A. (1995). The Legitimacy of Transnational Legal Institutions: Compliance, Support, and the European Court of Justice. American Journal of Political Science, 39(2), 459-89.

Hafner-Burton, E. M. (2013). Making Human Rights a Reality, Princeton; Oxford: Princeton University Press.

Hawkins, D. \& Jacoby, W. (2010). Partial Compliance: A Comparison of the European and Inter-American Courts of Human Rights. Journal of International Law and International Relations, 6(1), 35-85. 
Helfer, L. R. \& Slaughter, A. M. (1997). Toward a Theory of Effective Supranational Adjudication. Yale Law Journal, 107(2), 273-391.

Heyns, C. \& Viljoen, F. (2001). The Impact of the United Nations Human Rights Treaties on the Domestic Level. Human Rights Quarterly, 23, 483-535.

Hiebert, J. (2006). Parliament and the Human Rights Act: Can the JCHR Help Facilitate a Culture of Rights? International Journal of Constitutional Law, $4,1-38$.

\& Kelly, J. B. (2015). Parliamentary Bills of Rights. The Experiences of New Zealand and the United Kingdom, Cambridge: Cambridge University Press.

Hillebrecht, C. (2012). Implementing International Human Rights Law at Home: Domestic Politics and the European Court of Human Rights. Human Rights Review, 13(3), 279-301.

(2014). Domestic Politics and International Human Rights Tribunals. The Problem of Compliance, Cambridge: Cambridge University Press.

Hopkins, J. (2011). New Zealand. In D. Shelton, ed., International Law and Domestic Legal Systems. Incorporation, Transformation, and Persuasion, Oxford: Oxford University Press, pp. 429-47.

HRC (2001). Concluding Observations of the Human Rights Committee: The Netherlands, UN Doc. CCPR/CO/72/NET.

Hunt, M., Hooper, H. \& Yowell, P. (2012). Parliaments and Human Rights. Redressing the Democratic Deficit. Arts \& Humanities Research Council. AHRC Public Policy Series No. 5. www.ahrc.ac.uk/documents/projectreports-and-reviews/ahrc-public-policy-series/parliaments-and-human -rights-redressing-the-democratic-deficit/.

Hurd, I. (1999). Legitimacy and Authority in International Politics. International Organization, 53(2), 379-408.

Husa, J. (2010). Nordic Constitutionalism and European Human Rights. Mixing Oil and Water? Scandinavian Studies in Law, 55, 101-24.

(2011). The Constitution of Finland. A Contextual Analysis, Portland, OR: Hart Publishing.

ILA (2004). Final Report on the Impact of Findings of the United Nations Human Rights Treaty Bodies, Berlin: Committee on International Human Rights Law and Practice.

JCHR (2010). Enhancing Parliament's Role in Relation to Human Rights Judgments. Fifteenth report of session 2009-10. HL paper 85. Hc 455.

Kälin, W. (2012). Examination of State Reports. In H. Keller \& G. Ulfstein, eds., UN Human Rights Treaty Bodies. Law and Legitimacy, Cambridge: Cambridge University Press, pp. 16-72.

Keck, M. E. \& Sikkink, K. (1999). Transnational Advocacy Networks in International and Regional Politics. UNESCO, 89-101. 
Keller, H. \& Stone Sweet, A. (2008). A Europe of Rights. The Impact of the ECHR on National Legal Systems, Oxford: Oxford University Press.

Keller, H. \& Ulfstein, G. (2012). Conclusions. In H. Keller \& G. Ulfstein, eds., UN Human Rights Treaty Bodies. Law and Legitimacy, Cambridge: Cambridge University Press, pp. 414-25.

Kelly, J. B. (2011). Judicial and Political Review as Limited Insurance: The Functioning of the New Zealand Bill of Rights Act in 'Hard' Cases. Commonwealth and Comparative Politics, 49 (3), 295-317.

Krommendijk, J. (2014). The Domestic Impact and Effectiveness of the Process of State Reporting under UN Human Rights Treaties in the Netherlands, New Zealand and Finland. Paper-Pushing or Policy Prompting? Antwerp: Intersentia.

(2015). The Domestic Effectiveness of International Human Rights Monitoring in Established Democracies. The Case of the UN Human Rights Treaty Bodies. Review of International Organisations, 10 (4), 489-512.

Lavapuro, J., Ojanen, T. \& Scheinin, M. (2011). Rights-based Constitutionalism in Finland and the Development of Pluralist Constitutional Review, I-CON, 9 (2), 505-31.

Leblanc, L., Huibregtse, A. et al. (2010). Compliance with the Reporting Requirements of Human Rights Conventions. International Journal of Human Rights, 14(5), 789-807.

Locke, K. (2012). Interview with the author on 3 July 2012, Auckland, New Zealand.

Logie, J. (2012). Email from Jan Logie of 14 June 2012.

Lupu, Y. (2015). Legislative Veto Players and the Effects of International Human Rights Agreements. American Journal of Political Science 59 (3), 578-94.

Maori Party (2007). Report to the United Nations Committee on the Elimination of Racial Discrimination. http://tbinternet.ohchr.org/Treaties/CERD/Shared\% 20Documents/NZL/INT_CERD_NGO_NZL_71_9833_E.doc.

Martin, L. L. (2013). Against Compliance. In J. Dunoff \& M. Pollack, eds., Synthesizing Insights from International Law and International Relations, Cambridge: Cambridge University Press, pp. 591-610.

McQuigg, R. J. A. (2007). The Responses of States to the Comments of the CEDAW Committee on Domestic Violence. The International Journal of Human Rights, 11(4), 461-79.

Moravcsik, A. (1995). Explaining International Human Rights Regimes: Liberal Theory and Western Europe. European Journal of International Relations, 1 (2), 157-89.

MultiRights (2015). The International Human Rights Judiciary and National Parliaments, MultiRights Workshop, Oslo, 12-13 March 2015.

Nauclér, E. (2013). Speech to Finland's UN Women on 22 April 2013. 
Neumayer, E. (2005). Do International Human Rights Treaties Improve Respect for Human Rights? Journal of Conflict Resolution, 49(6), 925-53.

Niemi, H. (2003). National Implementation of Findings by United Nations Human Rights Treaty Bodies: A Comparative Study. Research Reports Åbo Akademi University, 20.

NZPD (2003). 14 October 2003. 612 NZPD 9158.

NZPD (2005a). 16 March 2005. 624 NZPD 19241.

NZPD (2005b). 12 May 2005. 625 NZPD 20555.

O'Flaherty, M. (2006). The Concluding Observations of United Nations Human Rights Treaty Bodies. Human Rights Law Review, 6 (1), 27-52.

OHCHR (2006). The Concept Paper on the High Commissioner's Proposal for a Unified Standing Treaty Body, UN Doc. HRI/MC/2006/2.

Ojanen, T. (2012). The Europeanization of Finnish law. Observations on the Transformations of the Finnish Scene of Constitutionalism. In K. Nuotio, S. Melander \& M. Huomo-Kettunen, eds., Introduction to Finnish Law and Legal Culture, Helsinki: Forum Iuris, pp. 97-110.

Oomen, B. (2013). The Rights for Others: The Contested Homecoming of Human Rights in the Netherlands. Netherlands Quarterly of Human Rights, 31 (1), 41-73.

Pesonen, P. \& Riihinen, O. (2002). Dynamic Finland. The Political System and the Welfare State, Tampere: Tammer-Paino Oy.

Pillay, N. (2012). Strengthening the United Nations human rights treaty body system. A report by the United Nations High Commissioner for Human Rights. www2.ohchr.org/english/bodies/HRTD/docs/HCReportTB Strengthening.pdf.

Pourgourides, C. (2010). Implementation of judgments of the European Court of Human Rights. Parliamentary Assembly. AS/Jur (2010) 36.

Pownews (2013). Europa beticht Nederland van discriminatie. 15 oktober 2013. www.powned.tv/uitzendinggemist/2013/10/pownews_472.html.

Radio New Zealand (2012). The United Nations Has Criticised New Zealand's Proposed Welfare Reforms for Breaching Human Rights, 22 May 2012: www .radionz.co.nz/news/national/106441/un-critical-of-nz-welfare-reforms.

Raustiala, K. (2000). Compliance and Effectiveness in International Regulatory Cooperation. Case Western Reserve Journal of International Law, 32, $387-440$.

Rieter, E. (2012). Het EHRM ontlasten: de rol van de nationale parlementen bij het toezicht op de naleving van het EVRM. In J. Gerards \& A. Terlouw, eds., Amici Curiae. Adviezen aan het Europees Hof voor de Rechten van de Mens, Boston: Martinus Nijhoff Publishers, pp. 221-30.

Risse, T., Ropp, S. C. \& Sikkink, K., eds. (1999). The Power of Human Rights: International Norms and Domestic Change, Cambridge: Cambridge University Press. 
Rosas, A. (2001). Finland. In R. Blackburn \& J. Polakiewicz, eds., Fundamental Rights in Europe. The European Convention on Human Rights and Its Member States, 1950-2000, Oxford: Oxford University Press, pp. 289-312.

Rutte, M. (2010). Knok voor vrijheid. De staat moet de baas zijn, NRC Handelsblad, 31 May 2010, 6.

Saul, M. (2015). Should the International Human Rights Judiciary Promote the Quality of Domestic Parliamentary Processes? Paper presented at The International Human Rights Judiciary and National Parliaments, MultiRights Workshop, Oslo, 12-13 March 2015.

Schmidt, M. G., Bayefsky, A. F. \& Rodley, N. (1997). Does the United Nations Human Rights Program Make a Difference? Proceedings of the Annual Meeting (American Society of International Law), 461-75.

Semb, A. J. (2012). Why (Not) Commit? Norway, Sweden and Finland and the ILO Convention 169. Nordic Journal of Human Rights, 30(2), 122-47.

Simmons, B. (2009). Mobilizing for Human Rights. International Law in Domestic politics, Cambridge: Cambridge University Press.

Smits-Baauw, G. \& Van Os, C. (2007). Geen Kind in de Cel. 'Het voelt niet recht'. Tijdschrift voor de Rechten van het Kind, 17(4), 2-5.

Spekman, H. (2011). Email from Hans Spekman to author of 28 May 2011 and email from Barbara Oomen of 14 June 2011.

Squatrito, T. (2015). Domestic Legislatures and International Human Rights Law: Legislating on Religious Symbols in Europe. Paper presented at The International Human Rights Judiciary and National Parliaments, MultiRights Workshop, Oslo, 12-13 March 2015.

Steiner, H. J. (2000). Individual Claims in a World of Massive Violations: What Role for the Human Rights Committee. In P. Alston \& J. Crawford, eds., The Future of UN Human Rights Treaty Monitoring, Cambridge: Cambridge University Press, pp. 15-53.

Sverdrup, U. (2004). Compliance and Conflict Management in the European Union: Nordic Exceptionalism. Scandinavian Political Studies, 27 (1), 23-43.

TK 2001/02a, 26691/22588, nr. 45.

TK 2001/02b, nr. 708.

TK 2001/02c, 28102, nr. 3.

TK 2003/04a, 26150, nr. 12.

TK 2005/06a, 29344, nr. 54.

TK 2003/04b, 19637, nr. 833 and 834.

TK 2003/04c, nr. 33, 1801-1812.

TK 2003/04d, nr. 91, 5847-5852.

TK 2005/06b 29344, nr. 54.

TK 2006/07, 19637, nr. 1085. 
TK 2008/09, 31001, nr. 69.

TK 2009/10, 32123 VI, nr. 11.

Tuori, Kaarlo. (2012). Landesbericht Finnland, unpublished work.

Tushnet, M. (1999). Taking the Constitution Away from the Courts, Princeton: Princeton University Press.

Waldron, J. (2005). Compared to What? Judicial Activism and New Zealand's Parliament. New Zealand Law Journal, 441-5.

Wood, B., Hassall, I. et al. (2008). Unreasonable Force. New Zealand's Journey towards Banning the Physical Punishment of Children, Wellington: Save the Children.

Zwingel, S. (2005). How Do International Women's Rights Norms Become Effective in Domestic Contexts? An Analysis of the Convention on the Elimination of All Forms of Discrimination against Women (CEDAW), https://d-nb.info/97814287X/34. 